\title{
Analysis of temperature, air humidity and wind conditions for the needs of outdoor thermal comfort
}

\author{
Ewelina Dec ${ }^{1 *}$, Bożena Babiarz ${ }^{1}$ and Robert Sekret $^{2}$ \\ ${ }^{1}$ Rzeszow University of Technology, Faculty of Civil Engineering, Environmental Engineering and \\ Architecture, Department of Heat Engineering and Air Conditioning, Aleja Powstańców Warszawy 6, \\ 35-959 Rzeszów \\ ${ }^{2}$ Czestochowa University of Technology, Faculty of Infrastructure and Environment, Institute of \\ Environmental Engineering, Department of District Heating, Heating and Ventilation, st. Brzeźnicka \\ 60 A, 42-200 Częstochowa
}

\begin{abstract}
On the thermal comfort of a man staying outdoor during the summer affect mostly meteorological factors, physical activity and the type of clothing. The work analyzed external air parameters, such as: temperature, relative humidity and wind speed, occuring in years 1997-2016. Meteorological data recorded at the Rzeszów-Jasionka station allowed to determine, among others, the occurrence of maximum daily and hourly temperatures of outdoor, the daytime and hourly air relative humidity, the hourly wind speed, as well as the relationship between these parameters. In recent years, it has been observed the increase of the number of hot and very hot days which indicates a warming of the climate. The duration of series of days with maximum daily temperature above $30^{\circ} \mathrm{C}$ is also prolonged, which is not comfortable for a person staying outside. During summer, during hot and very hot days, the average relative humidity remained below $70 \%$. The daily course of this factor was characterized by the opposite tendency with respect to temperature. The wind speed in the summer season varies from 0 to $6 \mathrm{~m} / \mathrm{s}$. On a daily basis, the increase in wind speed occurred in the afternoon hours which is consistent with the temperature characteristics. The occurrence of wind during the hottest hours causes a pleasant cooling of the organism.
\end{abstract}

\section{Introduction}

Issues related with the thermal comfort are widely discussed in the literature. There is a lot of information on the concept of thermal comfort as well as on how to maintain or evaluate it. The state of thermal comfort of a man is a state of its balanced thermal balance with the environment, with the simultaneous lack of a local discomfort. Feeling of comfort or discomfort is subjective and depends on the impact on the human body of the factors shaping the specific environment. The basic factors are: air temperature, humidity and its speed of movement [1]. The relative humidity of the air affects on the amount of the heat

* Corresponding author: $\mathrm{d} 313 @$ stud.prz.edu.pl 
discharged from the body during an evaporation. The intensity of an evaporation depends on the difference of partial pressure of water vapor on the surface of the skin and the water vapor contained in the air. The hot and humid air gives the impression of suffocating and stale, causing breathing problems [2]. The speed of an air movement affects on the human's thermal sensation by disturbing the heat exchange by convection. Too high speed of an air flow creates a feeling of discomfort, cooling down the body. Except of thermal elements of the microclimate, the personal thermal sensations are influenced by personal factors such as the type of clothing and physical activity. Clothing acts as an insulator in the process of heat exchange with the environment and it is responsible for the transport of the water vapor. Each type of clothing has its own thermal insulation properties which depend on the material it is made of, as well as the quantity of immovable air in it. The physical activity of a human influences on the metabolic heat production. Increasing the activity, makes the body produces more heat, which reduces the temperature of the air, which originally was considered as comfortable $[1,2,3]$. The analysis of individual meteorological factors, such as: air temperature, relative humidity and wind speed, allows referring to the norm [6], which for each of these parameters determines the comfort range for humans. Due to the lack of standards developed so far, which would determine the comfort of a person staying outside, reference was made to the standard [6] for interior rooms.

\section{The range of thermal comfort}

Optimal human values of air parameters ensure well-being, which give better effects of work and rest. For the assessment of the air condition, thermal comfort indicators have been introduced $[1,2,4]$. These are the criteria that allow to determine in what extent the level of the thermal comfort in a particular place has been reached. There is a large amount of data in the literature regarding comfort conditions for humans, developed on the basis of research. Professor Fanger [2] decided that the most favorable temperature for the summer period in rooms is $22-24^{\circ} \mathrm{C}$, while the relative humidity of the air should be in the range of $30 \div 70 \%$. According to Gliński [5], the optimal range of air parameters in the room is the temperature within $18-24^{\circ} \mathrm{C}$ and relative humidity below $70 \%$. For the summer season, the most comfortable for a man in Polish standards [6] is the temperature in the range $23-26^{\circ} \mathrm{C}$. It was considered that at this temperature, a well-being for a person in rest or doing light work is ensured, with relative humidity in the range of $40-60 \%$.

No standards have been developed so far for outdoor thermal comfort. The external environment does not always create conditions conductive to effective work or leisure, which is why people spend most of their time indoors. This is mainly due to the fact that improving thermal conditions by heating or cooling the open space is complicated and much more difficult than in the case of enclosed spaces.

By the term "external zone of human presence" should be understood the space outside the building, unlimited around the partitions. It can be a place of work or rest in the open air. People willingly spend their free time using various types of tourist attractions, visiting museums, which are sometimes located outside the building. Many restaurants and cafes have an outdoor area reserved for guests, however the period of use is severely limited by weather conditions. Participating in sporting events, stage performances or just relaxing in the park becomes difficult during summer heat.

Thermal conditions prevailing in external zones significantly affect their utilization level [7]. In areas where the air temperature in the summer exceeds $27-30^{\circ} \mathrm{C}$, and the relative humidity maintains at a high level, exceeding $70 \%$, it should be speaking not only about the thermal comfort inside rooms, but also in external zones. Although the recommendations of standards [6] in the field of thermal comfort have been set for indoor spaces, they can be successfully applied for external areas. The method of field tests was 
considered the most suitable for determining the thermal sensations of a man in open spaces [8]. Spagnolo and de Dear [9] conducted field tests in several locations: at railway stations, bus stops, ferry piers and parks. Based on these studies, they decided that the range of comfortable conditions for the external environment far exceeds the recommended value for indoor spaces. Other scientists: Nakano and Tanabe [10] examined the requirements for thermal comfort in partially external spaces. Their research has shown that users of semioutdoor environments have shown almost three times more tolerance in the temperature range than those which were determined to be comfortable for rooms.

Feeling of the thermal comfort in the open space is conditioned mainly by meteorological factors, which include: ambient temperature and relative humidity of the air, wind speed and solar radiation $[4,11]$. These factors, changing their intensity in the time and the space, affect the human organism, affecting not only on the well-being, but also the on the state of health. Currently, there are a large number of indicators that determine the thermal sensation of a man under specific weather conditions. One of the most commonly used is the effective temperature (TE), which describes the interaction of the real air temperature, relative humidity and speed of the air movement, on the thermal sensation of a man staying in the shade $[4,11]$. On the basis of the effective temperature and subjective thermal sensations of researched people, a scale of thermal sensations was created [12], which assigns effective temperature ranges to different thermal sensations. According to this indicator, an effective temperature between 21 and $26.9^{\circ} \mathrm{C}$ is considered comfortable for people dressed in light summer clothing and doing light work. At an effective temperature of $27^{\circ} \mathrm{C}$, people felt hot [12].

To develop conditions for external man-made zones guaranteeing his comfort, a detailed analysis of the factors shaping the external climate should be made. In the further part of the work, atmospheric factors such as air temperature, relative humidity and speed of wind occurring in the summer season, i.e. in the period from May to September, were analyzed using data obtained from the Rzeszów area.

\section{Analysis of meteorological data}

\subsection{Description of the database}

For the analysis, data of external air parameters were used in the years 1951-2016 for the Rzeszów - Jasionka meteorological station, received from the Institute of Meteorology and Water Management in Warsaw [13]. The collected data, which include: air temperature, relative humidity and wind speed, allowed to obtain significant observations. They relate, inter alia, to the occurrence of maximum daily and hourly outside air temperatures, daily and hourly relative humidity, hourly wind speeds, as well as the relationship between these parameters. The data on external air parameters from the period of twenty years between 1997 and 2016 were analyzed in detail.

\subsection{Temperature data}

In the article were analyzed meteorological data, which affect on the comfort of a person staying in the outdoor zone during the summer heat. Undoubtedly, the maximum daily ambient temperature is a great importance here. Data on the maximum daily air temperature from the period of twenty years 1997-2016 were analyzed. From this time five years were selected during which the air temperature exceeded $34^{\circ} \mathrm{C}$ and focused on them the most. Figure 1 shows the course of maximum daily temperature for five selected summer seasons in the years: 2005, 2007, 2012, 2013, 2015. 


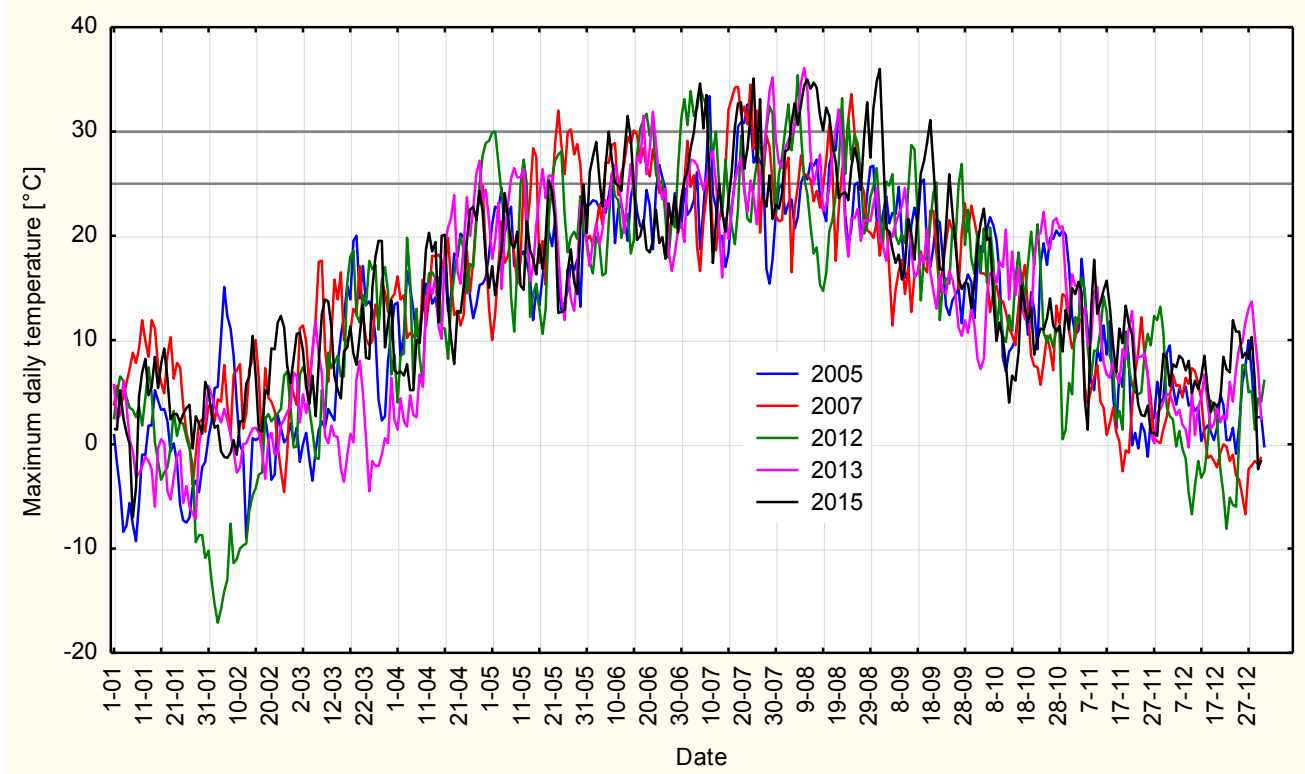

Fig. 1 Maximum daily air temperatures that occurred in 2005, 2007, 2012, 2013, 2015.

In climatology $[4,14]$ there is a temperature criterion that distinguishes particularly warm days. A hot day is a day with a maximum daily temperature equal to or above $25^{\circ} \mathrm{C}$, and a heat day is considered a day with a temperature equal to or higher than $30^{\circ} \mathrm{C}$. Based on meteorological data [13] with the maximum daily temperature from 1951-2016, there were chosen months in which heat days occurred. For the Rzeszów - Jasionka meteorological station, these were the months from May to September, which for the needs of this article were defined as the summer season.

Figure 2 shows the characteristics of occurrence of days with a defined maximum daily temperature, ranked in ascending order, as a function of the number 134 of the hottest days (with temperature above $20^{\circ} \mathrm{C}$ ), as the average of 20 years from 1977-2016.

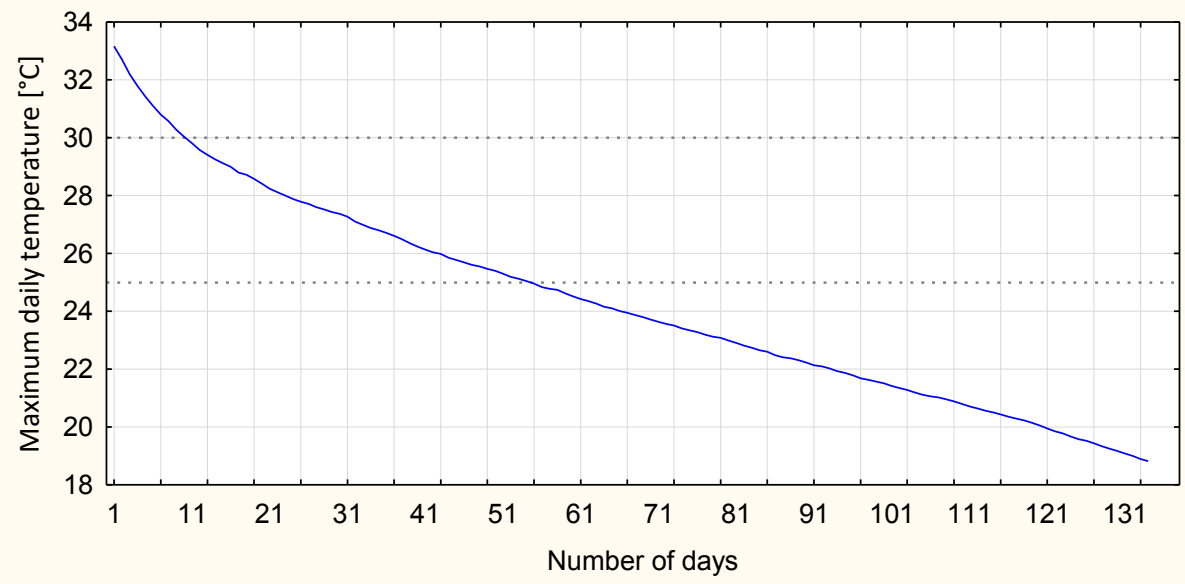

Fig. 2 The average number of days of occurrence of a specific ambient temperature for twenty years from the period 1997-2016. 


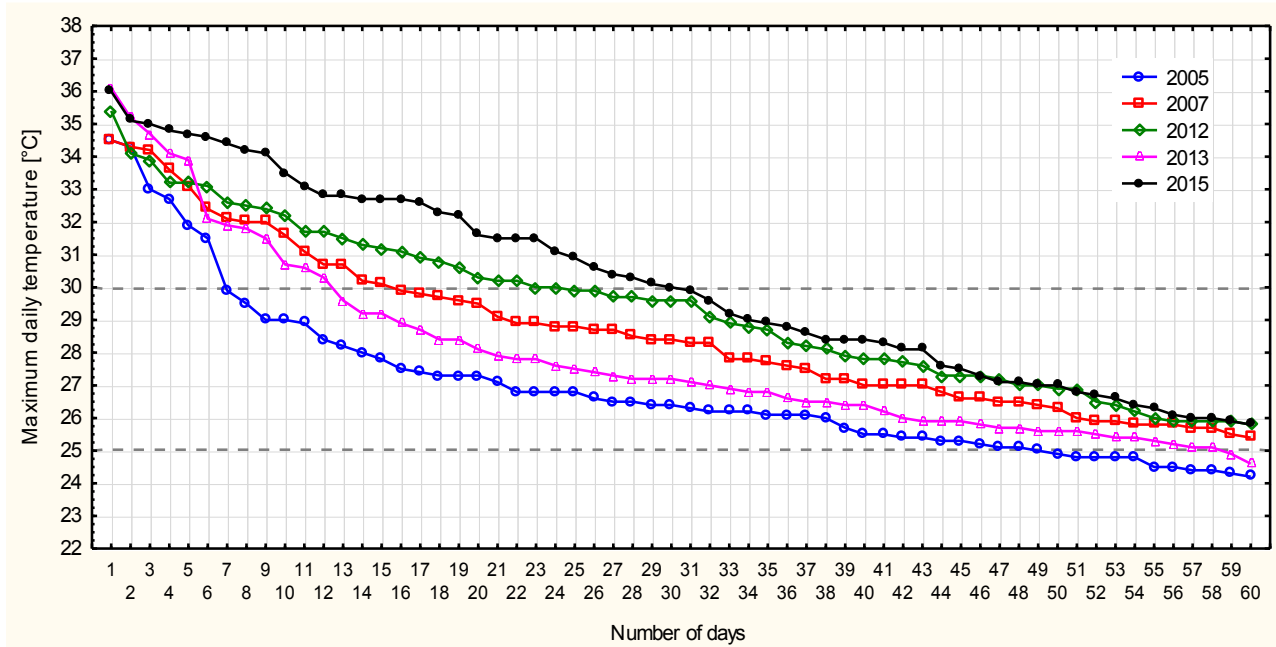

Fig. 3 Number of days of occurrence of a specific daily ambient temperature for five summer seasons with a maximum temperature of $34^{\circ} \mathrm{C}, 60$ warmest days.

The temperature course for individual days (Figures 4 is characterized by a similar trend. The biggest differences in particular years occur at temperatures higher than $25^{\circ} \mathrm{C}$.

Meteorological research clearly states the global warming in Europa in recent years. This is evidenced by the increase in the seasonal value of the ambient temperature both in the winter season and in the summer period $[15,16]$. A significant impact on climatic conditions has an increase in the occurrence of extreme events, which include, among others, heat waves. In meteorology [14], this term means a series of days, at least 3, with a temperature exceeding $30^{\circ} \mathrm{C}$. The number of hot and very hot days that occurred in the last 20 years in Rzeszów, listed chronologically showed Figure 4.

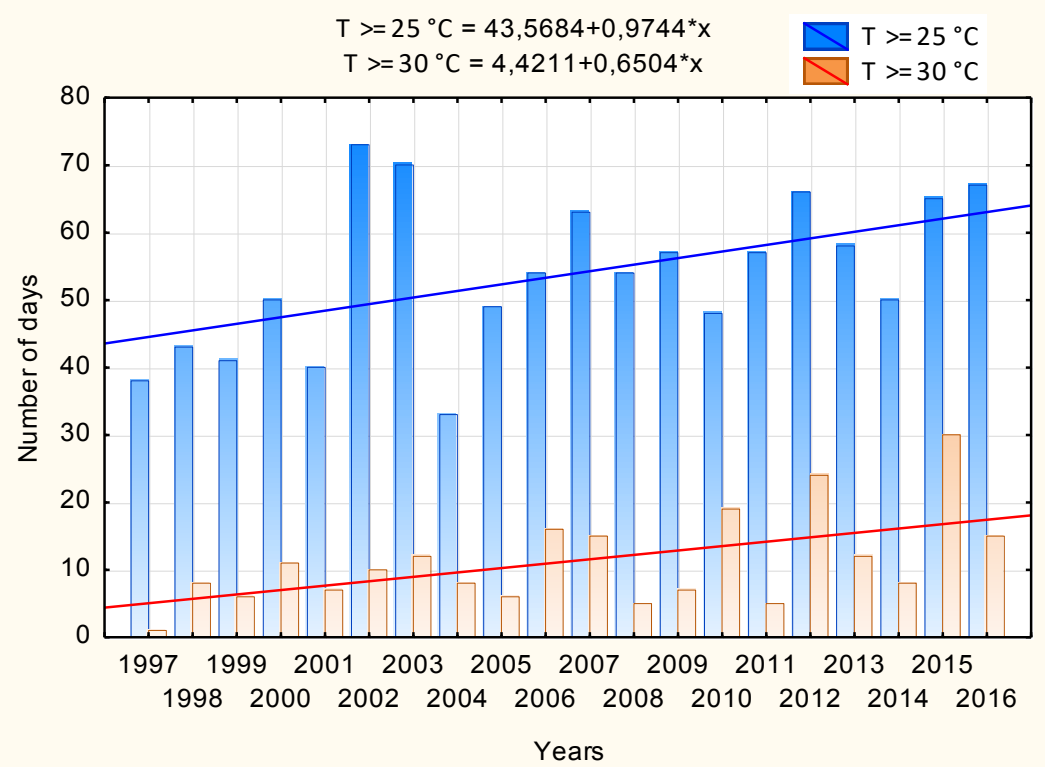

Fig. 4 The number of hot and very hot days that occurred in the years 1997-2016 in Rzeszów. 
The presented data in Figure 4 indicate an increase in the incidence of both the number of hot and very hot days. Analyzing the occurrence of days with temperatures exceeding $30^{\circ} \mathrm{C}$ in $1997-2016$, it can be concluded that they most often appeared as single days. Heat waves are particularly unfavorable from the point of view of thermal comfort, which primarily are exposed children and the elderly. With the increase in the incidence of hot days, there is a sharp increase in mortality. The influence of hot weather on the human organism has been described in detail in article [17]. This phenomenon usually appeared up to three times in one season and the length rarely exceeded three days. It is worth noting that in recent years, the sequences of hot days have significantly extended. In 2007 and 2010 there were eight of them, in 2012 - nine, while in 2015, the heat wave lasted 13 days.

\subsection{Relative humidity}

Having the data of average daily relative humidity, their monthly averages were calculated. In order to describe the variability of this meteorological factor during the year, Figure 5 shows the distribution of monthly average relative humidity from the period of 20 years (1997-2016) and average monthly values of relative humidity for the five warmest seasons.

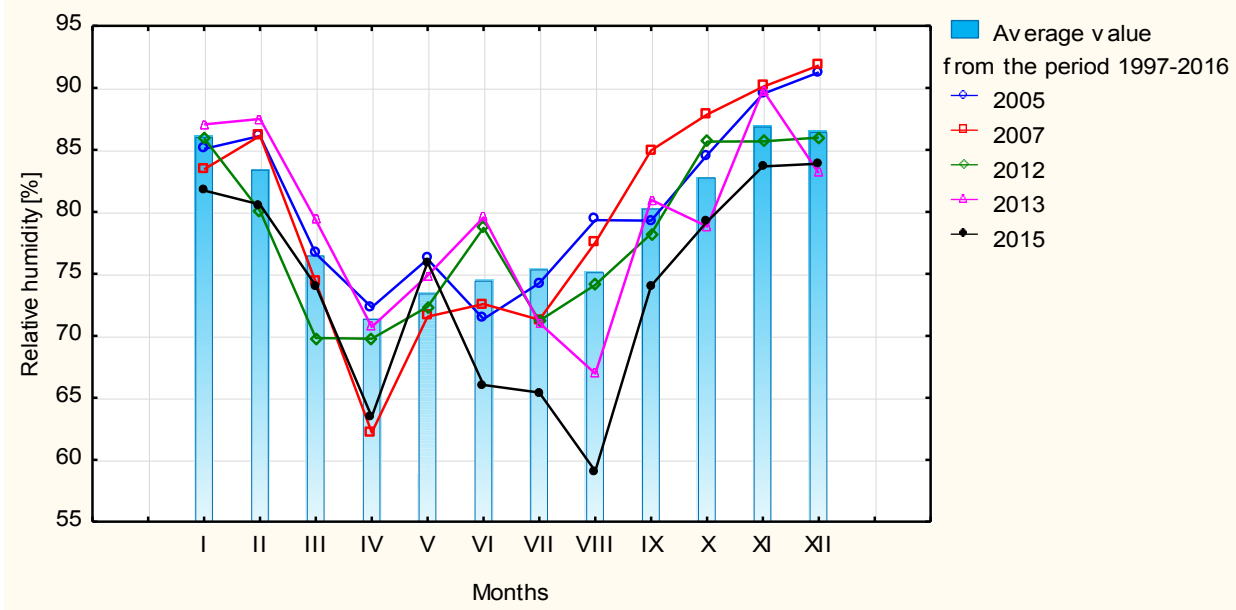

Fig. 5 Average monthly values of relative humidity for the five warmest seasons in years 1997-2016 and average monthly values from period 20 years between 1997-2016.

Analyzing the values of relative air humidity throughout the whole year, it can be seen that its lowest values occur from April to September, that is in the months belonging to the first half of the summer. The same type of humidity variability occurs both over a period of 20 years and during the five selected warmest years. The average relative humidity in the summer season is about $75 \%$. Air humidity is characterized by high variability in both monthly and daily periods.

\subsection{Wind speeds}

An important element shaping the external environment is the wind. Based on meteorological data [13], the hourly wind speeds that occurred at the Rzeszów-Jasionka meteorological station in the year 2015 were analyzed, with particular attention being paid to the summer period. The frequency of occurrence of the speed was calculated, as shown in Figure 6. The most frequent wind speed recorded during the period is in the range from 
0 to $6 \mathrm{~m} / \mathrm{s}$. Higher wind speeds $(7-12 \mathrm{~m} / \mathrm{s})$ appeared much less frequently. There were also single days when the wind speed was $19 \mathrm{~m} / \mathrm{s}$. Considering only the period from May to September, it was noticed that the wind speed was lower. The most often recorded in this season wind with speeds of $0-4 \mathrm{~m} / \mathrm{s}$. It should be noted that for relatively long time, windless conditions prevailed for $14 \%$ of the time. Less than $9 \%$ of the studied period was the state with a wind speed of $5 \mathrm{~m} / \mathrm{s}$, while a higher $6-9 \mathrm{~m} / \mathrm{s}$ lasted less than $4 \%$ of the time. There were also isolated cases of wind speeds up to $12 \mathrm{~m} / \mathrm{s}$.

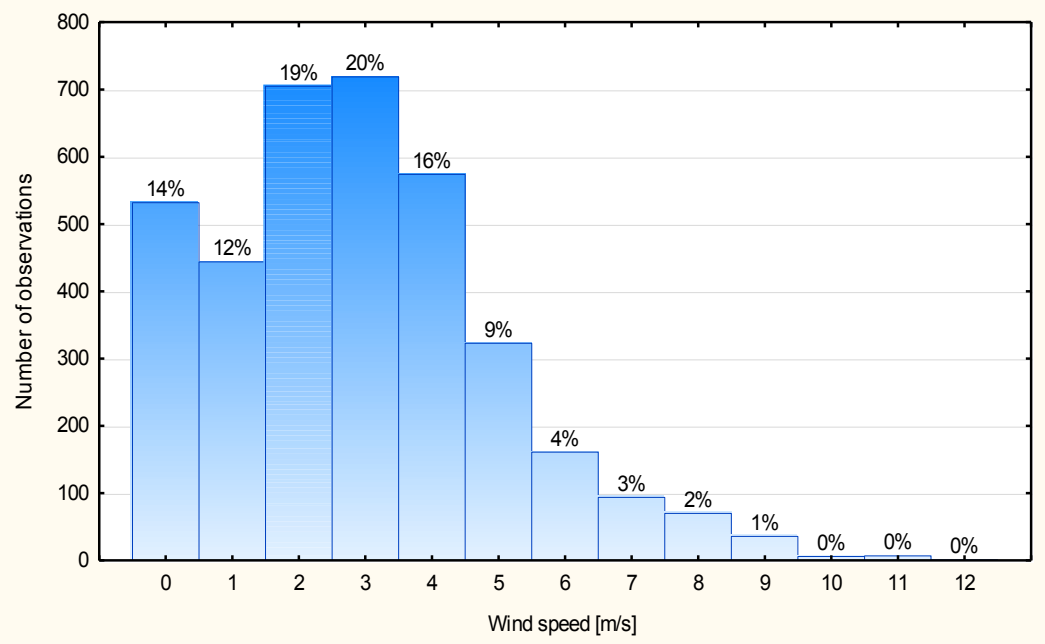

Fig. 6 Frequency of the specific wind speed in the summer of 2015.

In relation to the thermal comfort of a person staying outside, it is important the change of the wind speed within 24 hours as shown in Figure 7.

\subsection{Evaluation of thermal comfort in the outdoor zone during a hot day}

From the point of view of outdoor thermal comfort, the relationship between relative humidity, the temperature of the outside air and the wind speed is important.

Analyzing these parameters in the annual cycle as well as in the diurnal period, the inverse dependence between the relative humidity and the air temperature is strongly visible. In days with high temperatures lower values of relative humidity are recorded. During hot and very hot days, the average relative humidity is around $60 \%$. Its value does not generally exceed $70 \%$, which means that the relative humidity during the days with the temperature above $25^{\circ} \mathrm{C}$ falls within the range of standards for thermal comfort [6]. The average daily humidity of days with the temperature below $25^{\circ} \mathrm{C}$ was $73.5 \%$.

It is also interesting to analyze the hourly distribution of air temperatures and relative humidity. The warmest day in $2015(01 / 09 / 2015)$ was selected when the temperature exceeded $35^{\circ} \mathrm{C}$ (Figure 7). The horizontal dashed lines in appropriate colors indicate permissible values of individual parameters in terms of thermal comfort in the external zone (Figure 7). 


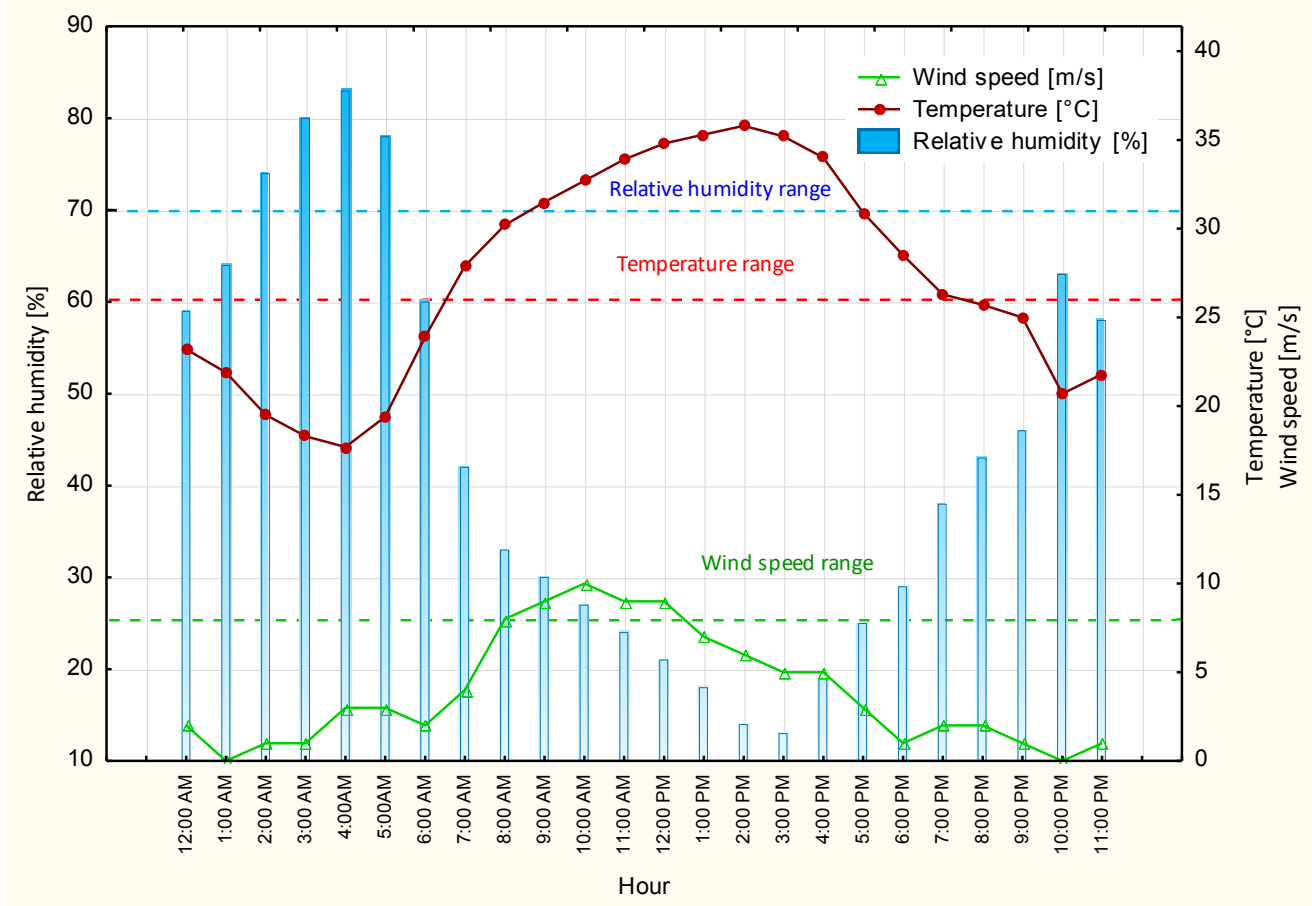

Fig. 7 Hourly air parameters occurring on 01/09/2015.

The line of instantaneous air temperature, measured every hour, reaches the highest values around noon hours. The exact opposite relationship can be observed for relative humidity. Its value is highest at night, while during the day, especially at noon, it drops significantly. This trend is characterized by all warm days in the climate of Poland. During the analyzed day, the air temperature already at 8:00 o'clock exceeded $30^{\circ} \mathrm{C}$, to reach $34.8^{\circ} \mathrm{C}$ at 2:00 pm. Almost all day, from 7:00 to 19:00, the temperature did not drop below $26^{\circ} \mathrm{C}$, thus exceeding the upper limit of thermal comfort adopted by Polish standards [6]. The relative humidity difference at these hours was $29 \%$, while within 24 hours it changed by as much as $70 \%$. Lowering the relative humidity during a simultaneous increase in the ambient temperature is advantageous from the point of view of thermal comfort.

The wind speed is also important here. The norm [6] assumes that the speed of air movement in the zone of human presence in the room can not exceed $0.3 \mathrm{~m} / \mathrm{s}$. In outdoor areas, it is necessary to talk about higher air velocities caused by wind. During very hot days, especially in the afternoon (when there are the highest daily air temperatures), the wind reaches the highest speeds, which positively affects the human's thermal sensation, resulting in a pleasant cooling of the body. When analyzing the influence of wind on thermal comfort in the external zone, one should pay special attention to the occurrence of wind with a speed not exceeding $1 \mathrm{~m} / \mathrm{s}$ and over $8 \mathrm{~m} / \mathrm{s}$ [4]. Wind with a speed in the range of $0-1 \mathrm{~m} / \mathrm{s}$ is perceived as silence. Windless conditions favor the stagnation of air and the impurities contained in it, making it difficult to transfer heat from the human body to the environment. However, winds, whose speed exceeds $8 \mathrm{~m} / \mathrm{s}$, are strong winds, the occurrence of which leads to the cooling down of the human body [4]. When analyzing the influence of wind on outdoor thermal comfort, the height of the position zone should be taken into account. The International Biometeorology Association recommends a standard height of $1.2 \mathrm{~m}$. The speed of $8 \mathrm{~m} / \mathrm{s}$ measured at $10 \mathrm{~m}$ corresponds to a speed of $5.2 \mathrm{~m} / \mathrm{s}$ at a height of $1.2 \mathrm{~m}$. During the hottest day of 2015 (Figure 7), between 8:00 o'clock and 12:00 there was a strong wind, but windless conditions appeared in the night. 


\section{Summary}

The collected meteorological data confirm the high variability of selected parameters shaping the weather condition in Poland in both the annual and seasonal cycles. The warmest period is from May to September, when temperatures exceed $30^{\circ} \mathrm{C}$. In recent years, an increase in the number of very hot days has been observed, which indicates a significant change in climate parameters with a tendency to its warming. The duration of hot weather sequences is also longer, which is not comfortable from the point of view of a person staying outside, and may even lead to harmful effects on him. It should be noted that in the summer there is a lot of sunlight, which increases discomfort during hot and very hotdays. The characteristics of the data on the intensity of solar radiation would allow on a broader analysis of the impact of atmospheric factors on a person staying outside during very hot days. This issue will be the subject of further articles.

\section{References}

1. Skrzyniowska D., 4-Ś R. 109, p. 15-35 (2012)

2. Fanger P.O., Popiołek Z., Wargocki P., Środowisko wewnętrzne. Wplyw na zdrowie, komfort $i$ wydajność pracy (2003)

3. Dec E., Pisarev V., JCEEA-64-01, p. 335-346 (2017)

4. Błażejczyk K., Bioklimatyczne uwarunkowania rekreacji i turystyki w Polsce. Warszawa (2004)

5. Gliński M., Optymalizacja parametrów powietrza w pomieszczeniach. Miejscowa wentylacja wywiewna. (2007)

6. PN-78/B-03421. Wentylacja $i$ klimatyzacja. Parametry obliczeniowe powietrza wewnętrznego w pomieszczeniach przeznaczonych do statego przebywania ludzi

7. Zhou Z., Hong, Ch., Deng Q., Mochida A., JAABE vol.12 no.1, p. 73-79 (2013)

8. Lin, T.P., Hwang, R.L., Cheng, M.J, ICB 17, p. 150-153 (2005)

9. Spagnolo, J., de Dear, R.J., 38(5), p. 721-738 (2003)

10. Nakano, J., \& Tanabe, S., 110(2), p. 543-553 (2004)

11. Wereski S., Wereski S., Klimat odczuwalny Leska na podstawie normalnej temperatury efektywnej (NTE) i temperatury radiacyjno-efektywnej (TRE) (2009)

12. Bajbakova E.M., Nevraev G.A., Čubukov L.A., Metodika analiza klimata kurortov i meteorologičeskich uslovij klimatoterapii. Očerki po klimatologii kurortov (1963)

13. Instytut Meteorologii i Gospodarki Wodnej - Państwowy Instytut Badawczy (IMGWPIB)

14. Kossowska-Cezak U., Prace geograficzne, z. 123, p.143-149 (2010)

15. Cebulak E., Limanówka D., Dni z ekstremalnymi temperaturami powietrza w Polsce. Wahania klimatu $w$ różnych skalach przestrzennych $i$ czasowych Instytut Geografii i Gospodarki Przestrzennej Uniwersytet Jagielloński, p. 185-194 (2007)

16. Sekret R., Wilczyński J., RE 4(95) p. 58-63 (2011)

17. Krzeszowiak J., Pawlas K., MŚ, 3(18) p. 47-55 (2015) 